\title{
IDENTIFICATION OF STREPTOCOCCUS MUTANS SEROTYPES IN DENTAL PLAQUE BY FLUORESCENT ANTIBODY TECHNIQUES
}

\author{
Ella M. Grenier, W. C. Eveland and W. J. Loesche \\ Department of Epidemiology, School of Public Health and Department of \\ Oral Biology, School of Dentistry, University of Michigan, Ann Arbor, \\ Michigan 48104, U.S.A.
}

\begin{abstract}
Summary-The presence of Streptococcus mutans in dental plaque may be related to human dental caries. The cultural identification of this organism in plaque is not likely to be used routinely in a clinical or epidemiological situation. In an effort to develop a simpler diagnostic means of identifying Strep. mutans in plaque, antisera were prepared for the 5 known serotypes of Strep. mutans. These immune sera were conjugated with fluorescein isothiocyanate, fractionated to obtain the gamma globulin and titrated against their homologous antigens to obtain working titres. These antisera were compared with cultural methods for their ability to detect Strep. mutans in plaque samples. Nonspecific fluorescent antibody reactions and weak cross-reactions were essentially eliminated by applying eriochrome black as a counterstain, affer plaque and conjugated antiserum had been incubated. The results suggest that the fluorescent antibody is more sensitive than cultural methods in the detection of Strep. mutans in dental plaque.
\end{abstract}

\section{INTRODUCTION}

Streptococcus mutans is capable of causing caries in hamsters (KEYES, 1968), germfree rats (GIBBons et al., 1966) and monkeys (BowEN, 1969). This organism can be isolated from humans with active caries (ZINNER et al., 1965; GibBOns et al., 1966; KrasSE et al., 1968; De StoppelaAR, van Houte and Backer-Dirks, 1969; LitTleton, KaKeHashi and FitzGERALD, 1970a). Several clinical studies using either cultural or fluorescent antibody reagents have attempted to associate Strep. mutans with human caries. KRASSE et al. (1968) found significantly higher Strep. mutans levels in plaque removed from individuals with active caries than in plaque removed from subjects diagnosed as caries inactive. DE STOPPELAAR et al. (1969) reported a positive correlation between the presence of Strep. mutans in plaque samples obtained from the buccal smooth surface of the lower right second molar and caries of that surface. LiTTLETON et al. (1970a) found the levels of Strep. mutans in plaque samples to be greater in boys with unrestored carious lesions. In plaque samples taken from over a carious lesion, Strep. mutans accounted for about 41 per cent of the colonies on mitis-salivarius agar, where as, in plaque taken from noncarious teeth in the same mouth, Strep. mutans averaged only 1 per cent of the colonies (LiTTLETON, KAKEHASHI and FirzGERALD, 1970b).

Cultural studies are time consuming and subject to many variables as the samples are usually collected and stored for varying periods of time prior to dispersion and plating on mitis-salivarius agar (JORDAN, ENGLANDER and LIM, 1969). ZINNER and 
JABLON (1968) have adapted the fluorescent antibody technique (FA) for the detection of Strep. mutans in plaque samples. This procedure has been used to demonstrate the occurrence of various Strep. mutans serotypes in clinical specimens (ZINNER and JABLON, 1967; DUANY, ZINNER and JABLON, 1970). However, the interpretation of the results is hampercd by cross-rcactions between cariogenic and non-cariogenic strains (ZINNER and JABlon, 1968). BratTHALl (1970) has separated Strep. mutans into 5 serotypes and has described an absorption scheme which eliminates most of the nonspecific cross-reactions between these serotypes (BRATTHALL, 1972a).

In the present investigation concurrent cultural and FA studies were performed on plaque samples to compare their ability to detect Strep. mutans. Nonspecific FA reactions with unrelated antigens and cross-reactions of heterologously related antigens were essentially eliminated by using an eriochrome black counterstain.

\section{MATERIALS AND METHODS}

Strains

The strains of Strep. mutans employed were obtained from Dr. L. A. Thomson and are listed in Table 1. These strains were grown in a combination of half strength Spirolate broth (Bioquest) and

TABLE 1. STRAINS OF STREPTOCOCCI USED IN THIS INVESTIGATION. Strep. mutans LISTED
ACCORDING TO THE BRATTHALL SEROTYPES (1970)

* ATCC: American Type Culture Collection, Rockville, Maryland

half strength Brain Heart Infusion broth (Bioquest) to which 0.5 per cent yeast extract was added. After $48 \mathrm{hr}$ growth, the cells were harvested by centrifugation. About $125 \mathrm{ml}$ of 0.4 per cent formalized saline was added to the packed cells, followed by further incubation at $37^{\circ} \mathrm{C}$ for 2 days with intermittent shaking. The cell material was then washed 3 times by centrifugation using normal saline, diluted to a No. 5 MacFarland standard and merthiolate added at a concentration of 1-10,000. These preparations were used as antigens for immunization.

\section{Immunization schedule}

The antigen suspensions were inoculated intravenously into 5-6 lb rabbits on the following schedule: day $1,0.5 \mathrm{ml}$; day $4,1 \mathrm{ml}$; day $7,1.5 \mathrm{ml}$; day $10,2.0 \mathrm{ml}$; day $13,2.5 \mathrm{ml}$ and day $16,3.0 \mathrm{ml}$ of the antigen suspension. Animals were exsanguinated 6-7 days after the last inoculation and the serum separated from the clot by centrifugation. This crude antiserum was then ready for conjugation.

\section{Conjugate preparation}

Initial precipitation of the globulins was accomplished by mixing equal parts of the serum with cold saturated $\left(\mathrm{NH}_{4}\right)_{2} \mathrm{SO}_{4}$ and allowing this mixture to stand overnight at $4^{\circ} \mathrm{C}$. The precipitate was 
harvested by centrifuging in the cold at $10,000 \mathrm{rev} / \mathrm{min}$ for $30 \mathrm{~min}$. The precipitate was redissolved in 0.85 per cent saline and if any colour was apparent, reprecipitation with $\left(\mathrm{NH}_{4}\right)_{2} \mathrm{SO}_{4}$ and recentrifugation was carried out immediately. If reprecipitation was not necessary, the solution was dialyzed overnight at $4^{\circ} \mathrm{C}$ in buffered saline (pH 7.6) to remove sulphate ions.

Conjugation was done by the method of MARShall, EvelaNd and SMITH (1958) modified by using $0.025 \mathrm{mg}$ of fluorescein isothiocyanate per $\mathrm{mg}$ protein. This mixture was stirred overnight at $4^{\circ} \mathrm{C}$ and then dialysed in phosphate buffer $(\mathrm{pH} 6 \cdot 3)$ overnight at $4^{\circ} \mathrm{C}$. The conjugated proteins were then passed through a DEAE column (RIGGs, LOH and EVELAND, 1960) and the fractions containing the purified gamma globulin collected and dialysed overnight in phosphate buffered saline (PBS) (pH $7 \cdot 6 \cdot 7 \cdot 8$ ). Each conjugated antiserum was titrated with its homologous antigen and the highest dilution of antiserum giving a $4+$ reaction was the working titre used in the fluorescent antibody tests. The fluorescein to protein ratios of all conjugates were checked by the method of WELLS, MIILER and NADEL (1966), and were found to be in the acceptable range of 1.5 to 4.0 molar ratio (Goldman, 1968).

\section{Fluorescent antibody staining}

Smears of either dental plaque or the antigen suspension were incubated with the working titre of the conjugated antiserum in a moist chamber at room temperature for $30 \mathrm{~min}$. Initially, the smears were rinsed with PBS, mounted in buffered glycerine $(\mathrm{pH} \mathrm{7.6)}$ and examined with a Zeiss GFL microscope with a Osram $200 \mathrm{~W}$ mercury vapour arc lamp and a dark field condenser. The optics consisted of a $\times 40$ oil immersion objective and $\times 10$ occulars. The following filters were used: excitation filter BG12, barrier filters OG4/GG4 in combination. In later experiments, a counterstain was applied to provide a contrast between the FA-stained cells and the non-FA-stained cells. A 1:20 dilution of aluminium chelated eriochrome black (HALL and HANSEN, 1962) was left on the smears for 10-15 sec after which time the slides were rinsed with PBS and distilled water before being mounted. Usually 4 different plaque smears were placed on a slide to be stained with each conjugated antiserum.

The intensity of fluorescence was recorded by the symbols recommended by MooDY, ELLIS and UPDYKE (1958). Photomicrographs of suitable smears were taken using Anscochrome 200 film (ASA 200-24 DIN) with an exposure time of 50-60 sec.

\section{Collection of plaque samples}

Samples of plaque to be used for the FA study were collected from the mandibular right premolar and molar teeth of 14 to 16-yr-old boys. A Stimudent tooth pick was used to remove buccal and approximal plaque. The tooth-pick was then placed in a small vial containing 1-2 $\mathrm{ml}$ of a reduced transport fluid (RTF) (LOESCHE, HocKETT and SYED, 1972). The RTF-plaque suspensions were gently dispersed by agitation with capillary pipettes. The suspensions were smeared on glass slides and heat fixed. If the FA tests could not be done immediately, the slides were stored in the freezer.

Samples of plaque to be cultured were collected by passing sterile unwaxed dental floss approximally between the distal of the mandibular left second premolar and the mesial of the mandibular left 1st molar. The floss carrying the plaque sample (approximately 1 in. in length) was introduced into a tube containing $10 \mathrm{ml}$ of the RTF. These tubes were returned to the laboratory where the plaque samples were dispersed by sonifying for $10 \mathrm{sec}$ at the highest intensity provided by a Model W185D Sonifier (Ultra Sonic Inc.) equipped with a microtip. The dispersed plaque suspensions were serially diluted and $0.05 \mathrm{ml}$ aliquots of appropriate dilutions were plated on MM10-5 per cent sucrose medium. This medium is a modification of the M10 medium of CALDWELL and BRYANT (1966) in which the volatile fatty acids were omitted and various nutrients known to be required by certain members of the oral flora were provided (LOESCHE et al., 1972). When 5 per cent sucrose is added to this medium, polysaccharide-forming colonies such as Strep. mutans, Strep. sanguis and Strep. salivarius are readily recognizable (LOESCHE and SYED, 1973). The inoculated plates were incubated at $37^{\circ} \mathrm{C}$ in an anaerobic glove box (ARANKI $e t$ al., 1969) for 7 days and then used for determination of total viable counts and Strep. mutans counts.

\section{RESULTS}

The working titres for the various conjugated antisera ranged from undiluted to 1:16 dilutions for the AHT strain of Strep. mutans and for the Strep. salivarius preparation (Table 2). When unabsorbed conjugated antisera were tested against the 
streptococcal vaccines, the homologous strains exhibited a strong $3+$ or $4+$ reaction (Table 2). Many weak and moderate cross-reactions occurred between the heterologous strains. Within the Strep. mutans serotypes, strong cross-reactions were observed between strain OIHI (serotype $d$ ) and strain AHT (serotype $a$ ). Also the LM7 conjugate (scrotype $e$ ) showed strong reactions with serotype $c$ strains.

Undesirable cross-reactions can be minimized by prior absorption of the antisera with the cross-reacting antigens (BRATTHALL, 1972a). A simpler procedure might be the use of a counterstain. In our experience, when smears were stained with eriochrome black after a specific reaction had occurred, cross-reactions did not manifest themselves. Thus, when the same unabsorbed conjugated antisera were retested against the five Strep. mutans serotypes and other oral streptococci, and then counterstained with eriochrome black, only green fluorescence of the homologous strains were observed (Table 3). The only exception was a $3+$ reaction between AHT (scrotype $a$ ) and the closely related OIHI (serotype $d$ ) (BRATTHALL, 1970).

In epidemiologic surveys FA reagents have been used to determine the presence of Strep. mutans in plaque samples that have been incubated for varying periods of time in growth media (ZINNER and JABLON, 1968; DuANY et al., 1970; BratTHALL, $1972 \mathrm{~b}$ ). The plaque growth is harvested by centrifugation and the sediment is stained with the appropriate FA reagents. In the present investigation, Strep. mutans was sought directly in plaque taken from various sites in the oral cavity by both FA methods and quantitative bacteriological culturing procedures.

The FA method showed that all the plaques sampled contained cells which gave a $4+$ reaction with serotypes $a$ and $d$ antisera (Table 4). Serotype $b$ cells were present in 74 per cent of the plaques; serotype $c$ cells in only 8 per cent and serotype $e$ was not detected. Positive results were reported only if morphologically identifiable cocci showed immunofluorescent staining. Clinical samples might show nonspecific staining on yeast cells, fungal or cellulose fragments and the nuclear material of leucocytes. Cultural methods showed that a single, approximal plaque from a different site in the same mouth at the same time was positive for Strep. mutans in 29 of 48 subjects. In the plaques positive for Strep. mutans, this organism accounted for 8.1 per cent of the total colony-forming units (CFU) on the non selective MM10 sucrose medium.

\section{DISCUSSION}

Both cultural and FA methods will permit the detection of Strep. mutans in plaque samples. Of the two procedures, the FA method might be the casiest to adapt to epidemiological studies and eventually to clinical diagnosis. Killed vaccines of Strep. mutans produced by conventional immunological procedures are apparently not capable of eliciting high titred antisera in rabbits. However, the fractionation procedure in which conjugates were passed through a DEAE column have reduced the titres somewhat, by removing much of the nonspecific material as well as the unreacted dye. As seen in Table 2, most of the positive $(2+$ or $3+)$ cross-reactions occurred with the Strep. mutans serotypes, while very few occurred between the 

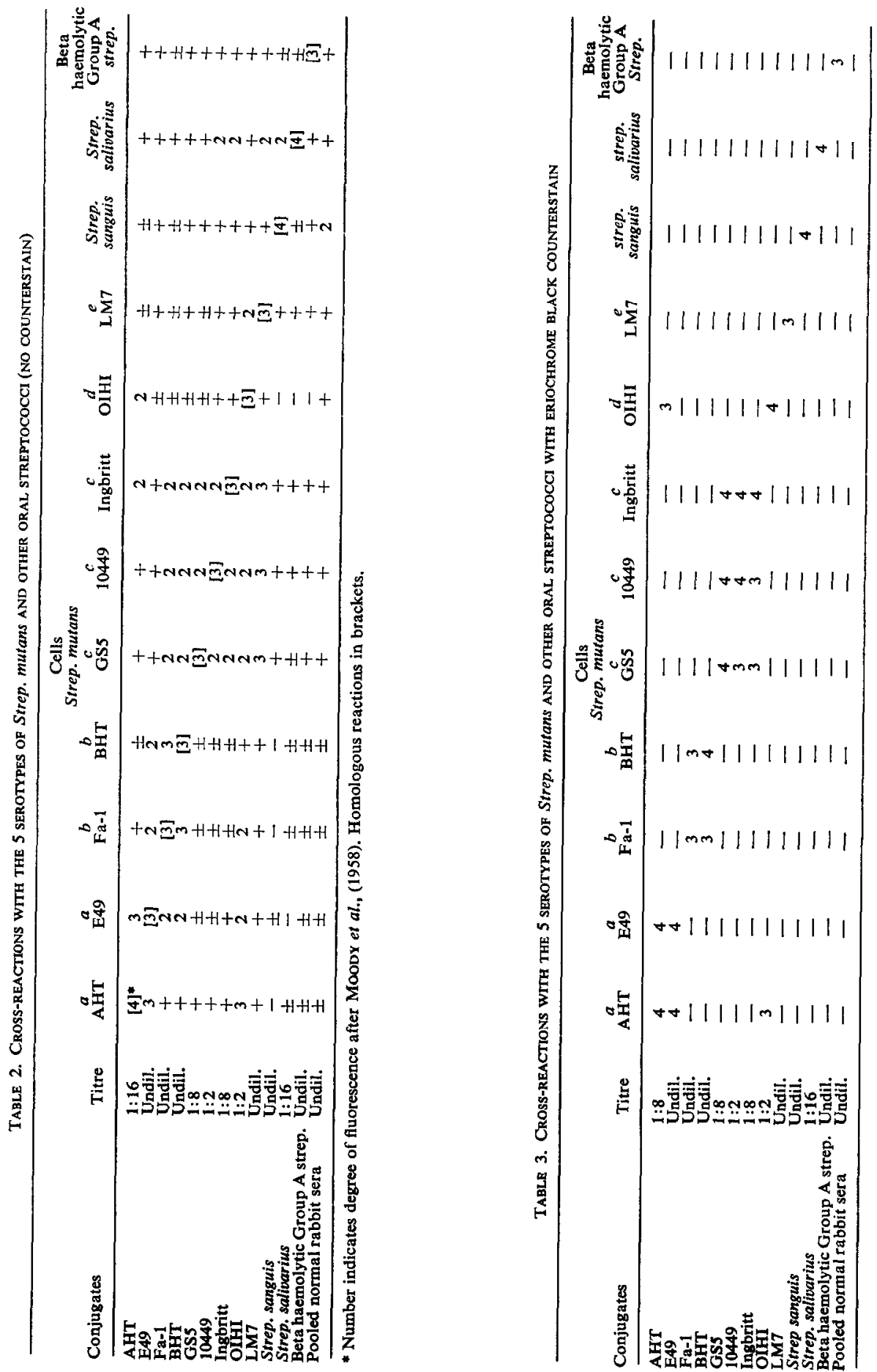
TABle 4. Distribution of Strep. mutans SEROTYPES IN A GROUP OF NORMAL hoYs PRONE TO CARIES

\begin{tabular}{|c|c|c|c|c|c|}
\hline \multirow[b]{2}{*}{$\stackrel{a}{\mathrm{AHT}}$} & \multicolumn{4}{|c|}{ Serotype and strain } & \multirow[t]{2}{*}{ Cultural } \\
\hline & $\stackrel{b}{F a-1}$ & GS 5 or 10449 & $\stackrel{d}{\text { OIHI }}$ & $\stackrel{e}{\mathrm{LM}} 7$ & \\
\hline $\begin{array}{l}51 * / 51 t \\
100 \%\end{array}$ & $\begin{array}{l}38 / 51 \\
74 \%\end{array}$ & $\begin{array}{l}2 / 24 \\
8 \%\end{array}$ & $\begin{array}{l}43 / 43 \\
100 \%\end{array}$ & $\begin{array}{l}0 / 43 \\
0 \%\end{array}$ & $\begin{array}{l}29 / 48 \\
60 \%\end{array}$ \\
\hline
\end{tabular}

* Number of plaque samples with $4+$ F.A. reactions.

$t$ Number of plaque samples tested.

different species. The conjugated pooled normal rabbit sera gave only a $2+$ reaction with Strep. sanguis.

ZINNER and JABLON (1968) attempted to eliminate these undesirable cross-reactions by absorption with known cross-reacting antigens, but found that the resultant sera were too weak to be effective. BRATTHALL (1970) demonstrated the presence of at least five Strep. mutans serotypes. In subsequent studies, he developed serotype specific sera by absorbing each antisera with one or more Strep. mutans strains (Bratthall, 1972a, 1972b). Nonspecific reactions due to conjugated normally occurring antibodies were avoided by treating all conjugated antisera with either Streptococcus pyogenes NCTC strain 8198 or with three unconjugated normal sera. The cross-absorption schemes proposed by Bratthall provide a means of obtaining specific sera against the various Strep. mutans serotypes. In our experience, these cross-absorptions require time, consume considerable amounts of the antisera and may weaken the homologous reactions.

These difficulties seem to be overcome by the use of the eriochrome black counterstain. It eliminated most of the nonspecific reactions which occurred between Strep. mutans and the other streptococcal species tested. The mode of action of the eriochrome black in this phenomenon is not known. It may either mask low fluorescent staining antibodies or displace them from the cell surface. The masking hypothesis would suggest that weak fluorescent reactions were reduced by an overlay of the counterstain, whereas strong reactions could not be overwhelmed in this manner although they may be diminished somewhat in intensity. It seems unlikely that the eriochrome black can completely mask a $3+$ nonspecific reaction and at the same time only dull a $3+$ specific reaction, as was seen with the serotype $e$ conjugate (Tables 2 and 3). Another explanation might be that the nonspecific antibodies are loosely bound to the cell surface and can be removed by the counterstain. The specific antibodies could be tightly bound to the cell surface and consequently not removed. This hypothesis would explain the ability of the serotype $e$ conjugate to give specific staining in the presence of the counterstain (Table 3). Further support for this view is the fact that pretreatment of cells with eriochrome black prevents any subsequent staining with specific antibody. This is interpreted to mean that the entire cell surface has been covered with eriochrome black and that no sites are then available for antibody reactions.

Some attempts were made to reduce nonspecific reactions by using pooled normal 
rabbit sera as a blocking reagent before applying a fluorescein conjugated antiserum. This procedure did enhance specific reactions by reducing the background staining, but the colour contrast was very poor as compared to slides with the counterstain. Blocking seemed to be unnecessary with the counterstain.

In the present investigation the FA reagents showed one or more serotypes of Strep. mutans in all of the subjects sampled. Serotype $a, d$ and $b$ were most common. Serotype $c$ was rarely found and serotype $e$ could not be detected. The occurrence of serotype $a$ in this population may be artificially high because an AHT conjugate was used. This conjugate cross-reacts with serotype $d$ and was the only example found in which the eriochrome black did not give serotype specific fluorescence. However, a conjugate made against strain E49, another serotype $a$ strain, did not cross-react with serotype $d$ in the presence of eriochrome black. Several smears were stained with AHT, E49 and OIHI FA conjugates. No cells stained with E49 whereas the eight plaques tested were all positive for AHT and O1H1. This would suggest that serotype $a$ was not present and that serotype $d$ was the most common serotype in our population. Br atTHALl (1972b) also found serotype $d$ to be widely distributed.

The FA method detected Strep. mutans in all the subjects, whereas the cultural methods showed Strep. mutans in only 60 per cent of the subjects. This difference in detection may be attributed to one or more reasons. Different sites in the same mouth were sampled. It is possible that Strep. mutans was not present in the single approximal site to the extent that it was present in the larger number of sites sampled for the FA measurement. If Strep. mutans was present in the cultured site, its numbers may have been so low that they were diluted out during plating beyond the point where detection was possible. The dilution range in which the plaques were cultured would permit the detection of one Strep. mutans colony in a population of 200-500 CFU. When the plaques were examined by FA methods, more than 1000 cells or potential CFU were screened. Thus with highly specific FA reagents, the FA procedure would be more sensitive. Another explanation for the differences in detection is that the culturing procedure will only measure viable bacteria, whereas the FA reagents will stain both the viable and nonviable cells originally present. The plaque samples were collected in the RTF which appears to be as good, if not better, than the VMG or SBL transport media in the preservation of Strep. mutans (RUNDELL et al., 1972; SYED and LOESCHE, 1972). However, none of the transport media currently available maintain the viability of all cells once they are removed from their natural environment, so some Strep. mutans cells probably became nonviable in the time between collection and actual plating of the sample which in the present study was about $12-15 \mathrm{hr}$.

A most serious objection would be that the greater percentages found by the FA methods were due in part to cross-reactions of some Strep. mutans antisera, i.e. $a$ and $d$, with non-mutans organisms. It was the purpose of this paper to show that this possibility can be minimized, if not eliminated, by the use of the eriochrome black counterstain.

Further studies are necessary in order to resolve these differences between cultural and FA methods in the detection of Strep. mutans. 
Acknowledgements-We wish to thank Brother EDWARD and Brother FrancIS of Boysville, Macon, Michigan for allowing us access to their students. Also Dr. Robert Murray and Dr. Gerald Wolfe of Tecumseh, Michigan and Dr. Salem SYed and Dr. HenRY LeE of the University of Michigan School of Dentistry assisted us in the collection of the samples. Mr. Mousa ABDUL-AHAD prepared the vaccines used in producing antisera for the FA tests and participated in the inoculation and bleeding of rabbits. Miss ArLine Walenga assisted in the cultural studies. This work was supported by grants from the National Institute of Dental Research: Grants No. DE03011-03, No. DE02731-05.

\begin{abstract}
Résumé-La présence du Streptococcus mutans dans la plaque dentaire pourrait être apparentée aux caries dentaires humaines. L'identification des cultures de cet organisme dans la plaque ne sera pas utilisée couramment dans une situation clinique ou épidémiologique. Dans un effort de développer un moyen de diagnostique plus simple pour identifier le Strep. mutans dans la plaque, on a préparé des antisérums pour les 5 sérotypes connus de Strep. mutans. Ces sérums immuns ont été conjugués avec l'isothiocyanate de fluorescéine, fractionnés pour obtenir la gamma globuline et titrés contre leurs antigènes homologues, pour obtenir des titres actifs. Ces antisérums ont été comparés avec des méthodes de culture pour leur capacité de détecter le Strep. mutans dans les échantillons des plaques. Les réactions des anticorps fluorescents non spécifiques et les réactions croisées faibles furent essentiellement éliminées en appliquant le noir eriochrome comme contre-colorant, après l'incubation de la plaque et des antisérums conjugués. Ces résultats suggèrent que l'anticorps fluorescent est plus sensible que les méthodes de culture pour la détection du Strep. mutans dans la plaque.
\end{abstract}

\begin{abstract}
Zusammenfassung-Das Vorhandensein von Streptococcus mutans in Zahnbelag kann beim Menschen auf Zahnkaries zurückgeführt werden. Es ist nicht anzunehmen, dass die Kulturidentifizierung von diesem Organismus in Zahnbelag normalerweise in einer klinischen oder einer epidemiologischen Situation benutzt werden wird. Um ein einfacheres diagnostisches Mittel zur Feststellung des Streptococcus mutans in Zahnbelag zu entwickeln, wurden für die 5 bekannten Serumtypen des Strep. mutans Antiseren präpariert. Diese immunen Seren wurden mit Fluoreszinisothiocyanat gepaart, was in Teile aufgespalten wurde, um Gammaglobulin zu erhalten und gegen igre homologen Antigene titriert, um Betriebstiter zu erhalten. Diese Antiseren wurden mit Kulturmethoden in Bezug auf ihre Fähigkeit verglichen, Strep. mutans in Zahnbelagproben zu ermitteln. Nicht spezifische fluoreszierende Antikörperreaktionen und schwache Kreuzreaktionen wurden im wesentlichen durch Eriochromschwarz als eine Gegenfärbung eliminiert, nachdem Belag und gepaarte Antiseren die Inkubationszeit durchgemacht hatten. Die Ergebnisse zeigten, dass der fluoreszierende Antikörper bei der Feststellung von Strep. mutans im Zahnbelag empfindlicher ist, als Kulturmethoden.
\end{abstract}

\title{
REFERENCES
}

Aranki, A., Syed, S. A., Kenney, E. B. and Freter, R. 1969. Isolation of anaerobic bacteria from human gingival and mouse cecum by means of a simplified glove box procedure. Appl. Microbiol. 17, 568-576.

BowEN, W. H. 1969. The induction of rampant dental caries in monkeys (Macaca irus). Caries Res. 3, 227-237.

Bratrhall, D. 1970. Demonstration of five serological groups of streptococcal strains resembling Streptococcus mutans. Odont. Revy 21, 143-152.

Bratthall, D. 1972a. Immunofluorescent identification of Streptococcus mutans. Odont. Revy 23, 181-196.

Bratthall, D. 1972b. Demonstration of Streptococcus mutans strains in some selected areas of the world. Odont. Revy 23, 401-410. 
Caldwell, D. R. and BRyant, M. P. 1966. Medium without rumen fluid for nonselective enumeration and isolation of rumen bacteria. Appl. Microbiol. 14, 794-801.

Carlsson, J., Söderholm, G. and Almfeldt, I. 1969. Prevalence of Streptococcus sanguis and Streptococcus mutans in the mouth of persons wearing full dentures. Archs oral Biol. 14, 243-249.

DE StoppelaAR, J. D., VAN HouTe, J. and BACKer-Dirks, O. 1969. The relationship between extracellular polysaccharide-producing streptococci and smooth surface caries in 13 year old children. Caries Res. 3, 190-199.

DUANY, L. F., ZINNER, D. D. and JABLON, J. M. 1970. Identification of types of potentially cariogenic streptococci on human tooth surfaces by the fluorescent antibody technique. J. dent. Res. 49, $1527-1529$.

EDWARDSSON, S. 1968. Characteristics of caries-inducing human streptococci resembling Streptococcus mutans. Archs oral Biol. 13, 637-646.

Fitzgerald, R. J., Jordan, H. V. and Stanley, H. R. 1960. Experimental caries and gingival pathologic changes in the gnotobiotic rat. J. dent. Res. 39, 923-935.

FitzGerald, R. J. and KeYes, P. 1960. Demonstration of the etiologic role of streptococci in experimental caries in the hamster. J. Am. dent. Ass. 61, 9-19.

Gibbons, R. J., Berman, K. S., Knoettner, P. and Kapsimalis, B. 1966. Dental caries and alveolar bone loss in gnotobiotic rats infected with capsule forming streptococci of human origin. Archs oral Biol. 11, 549-560.

Goldman, M. 1968. Fluorescent Antibody Methods, p. 126 Academic Press, New York.

Hall, C. T. and Hansen, P. A. 1962. Chelated azo dyes used as counterstains in the fluorescentantibody technic. Zbl. Bakt. Para. Inf. Hyg. 184, 548-554.

Jordan, H. V., Englander, H. R. and Lim, S. 1969. Potentially cariogenic streptococci in selected population groups in the western hemisphere. J. Am. dent. Ass. 78, 1331-1335.

KeYes, P. H. 1968. Research in dental caries. J. Am. dent. Ass. 76, 1357-1373.

KRASSE, B. 1966. Human streptococci and experimental caries in hamsters. Archs oral Biol. 11, 429-436.

Krasse, B., Jordan, H. V., Edwardsson, S. and Trell, L. 1968. The occurrence of certain cariesinducing streptococci in human dental plaque material with special reference to frequency and activity of caries. Archs oral Biol. 13, 911-918.

Littleton, N. W., Kakehashi, S. and FitzGerald, R. J. 1970a. Study of differences in the occurrence of dental caries in Caucasian and Negro children. J. dent. Res. 49, 742-751.

Litrleton, N. W., Kakehashi, S. and FitzGerald, R. J. 1970b. Recovery of specific "caries-inducing" streptococci from carious lesions in the teeth of children. Archs oral Biol. 15, 461-464.

Loesche, W. J., HocketT, R. and SYED, S. A. 1972. The predominant cultivable flora of tooth surface plaque removed from institutionalized subjects. Archs urul Biol. 17, 1311-1325.

LoEsCHe, W. J. and Syed, S. A. 1973. The Predominant cultivable flora of carious plaque and carious dentine. Caries Res. In press.

Marshall, J. D., Eveland, W. C. and SMith, C. W. 1958. Superiority of fluorescein isothiocyanate for fluorescein antibody technic with a modification of its application. Proc. Soc. expl.biol. Med. 98, 898-900.

Moody, M. D., Ellis, E. C. and UPDYKe, E. L. 1958. Staining bacterial smears with fluorescent antibody. IV. Grouping streptococci in dried smears with fluorescent antibody. J. Bact. 75, $553-560$.

Riggs, J. L., Loh, P. C. and Eveland, W. C. 1960 . A simple fractionation method for preparation of fluorescein labeled gamma globulin. Proc. Soc. exp. biol. Med. 105, 655-658.

Rundell, B., Thomson, L. A., Loesche, W. J. and Stiles, H. M. 1972. A new transport medium for the preservation of oral streptococci. Int. Ass. Dent. Res. Preprinted abstracts. 50th General Meeting. Abstract 576.

SYED, S. and LOESCHE, W. J. 1972. Survival of human dental plaque flora in various transport media. Appl. Microbiol. 24, 638-644.

Wells, A. F., Miller, C. F. and Nadel, M. K. 1966. Rapid fluorescein and protein assay method for fluorescent-antibody conjugates. Appl. Microbiol. 14, (2) 271-275.

Zinner, D. D., JABlon, J. M., ARan, A. P. and Saslaw, M. S. 1965. Experimental caries induced in animals by streptococci of human origin. Proc. Soc. exp. biol. Med. 118, 766-770.

ZINNER, D. D. and JABLON, J. M. 1967. An epidemiologic study of human strains of cariogenic streptncocci. Int. Ass. Dent. Res. Preprinted ahstracts. 45th General Meeting. Abstract 135.

ZINNER, D. D. and JABLON, J. M. 1968. Human streptococcal strains in experimental caries. In: The Art and Science of Dental Caries Research (edited by HARRIs, R. S.), pp. 87-109. Academic Press, New York. 